Vukman V. Bakić

Research Professor University of Belgrade Institute Vinča Laboratory for Thermal Engineering and Energy

Milada L. Pezo

Research Associate University of Belgrade Institute Vinča

Laboratory for Therma Engineering and Energy

Saša M. Stojković

Associate Professor University of Kragujevac Faculty of Technical Sciences Cačak

\section{Technical and Economic Analysis of Grid-Connected PV/Wind Energy Stations in the Republic of Serbia Under Varying Climatic Conditions}

In this paper technical and economic analysis of grid-connected PV/Wind energy systems located in the Republic of Serbia are presented. The technical and economic data, of the various grid-connected PV/Wind hybrid energy systems for three different locations: Novi Sad, Belgrade and Kopaonik, using the transient simulations software TRNSYS and HOMER were obtained. The results obtained in this paper show that locations and technical characteristics of the energy systems have an important influence on the amount of delivering electrical power to the grid. The $\mathrm{CO}_{2}$ emissions reductions, obtained on the basis of delivered electrical power to distribution networks are also analyzed. Economic analysis is carried out using Life Cycling Cost (LCC) method. The adoption and implementation of feed-in tariffs have a significant role in enhancing the implementation of technologies that use renewable energy resources.

Keywords: techno-economic analysis, grid-connected PV/Wind energy station.

\section{INTRODUCTION}

Energy sector nowadays needs to satisfy the criteria of energy efficiency, usage of RES (renewable energy sources), sustainable development and environmental protection. Usage of RES allows us to produce much needed energy for household, power industry and transport to function in a manner that is environmentally friendly and sustainable.

Hybrid energy systems combine energy obtained from different sources, such as solar panels and wind turbines to generate electrical power. "Small hybrid" electric system offers several advantages with regard to single systems. The peak operating times for wind and solar systems occur at different times of the day and year. The main reason for the choice of energy system depends on several parameters, such as cost and resources available. The cost of technical components and maintenance of hybrid system greatly affects the choices people make. People who are planning to set up a hybrid energy system for household choose a system with the low price of total investment and operational costs while those planning to generate electricity for sale focus on the long-term project revenue. It is necessary to investigate the potential of RES at given location. The right power generation location and method must be chosen.

Renewable energy sources like wind, solar, hydro,

Received: March 2015, Accepted: June 2015

Correspondence to: Dr. Vukman Bakić

Institute of Nuclear Science Vinca,

PO.Box. 522, 11000 Belgrade, Serbia

E-mail: bakicv@vinca.rs

doi:10.5937/fmet1601071B

(C) Faculty of Mechanical Engineering, Belgrade. All rights reserved biomass, etc. are sustainable and environmentally friendly. They have potential to be more widely used in all sectors of industry, transport, household, etc. Combining these renewable energy resources to form a hybrid system allows us to produce electrical power in a manner that is more profitable and more reliable compared to single-use of such systems.

An overview of the development, application and different approaches concerning hybrid systems with different RES are presented in [1-3]. The potential of solar and wind energy and economic viability of systems based on solar and wind energy have been analyzed in literature [2, 4]. Nema et al. [2] analyzed design, operational and technical conditions of currently available hybrid systems. They compared self-hybrid system and a system that in the absence of electricity uses excess energy which stored previously. Celik [5] proposed different sizing methods used for technoeconomic analysis of autonomous PV/wind hybrid energy systems. This method takes into account monthly variation in the required size of the renewable energy converts in order to find an optimum combination of system autonomy and cost. Economic analysis of PV energy systems with battery energy storage were analyzed in [6, 7]. HOMER (Hybrid Optimization Model for Electric Renewable) simulation software was used to perform the techno-economic analysis of the system. Experimental investigation [8] of the combination of solar and wind energies hybrid system for electrical generation under the Jordanian climate conditions is presented. The solar radiation intensity, the ambient temperature, the wind velocities and the output electrical power from the solar PV panels and wind turbine are parameters that have been 
measured. The electric power obtained from such system is used mainly for space heating and cooling. Caballero [9] presented a method for optimization of a small $\mathrm{PV} /$ wind grid-connected hybrid energy system without energy storage, in order to minimize the LCC (Life Cycle Cost) of the system, ensuring at the same time certain level of system reliability. Appropriate design of hybrid energy system connected to the grid and without energy storage is examined in [10, 11]. Supriya and Siddarthan [12] presented a method based on linear programming in order to minimize the LCC of a PV/wind hybrid energy system grid-connected. Ismail et al. [13] optimized a hybrid system that comprises of Photovoltaic (PV) panels, a battery system, and a microturbine as a backup power source for a remote community in Palestine. Alsayegh et al. [14] analyzed grid-connected hybrid RES systems. This paper deals with problems and challenges concerning reliability and the instability of grid-connected energy systems.

There are a lot of papers dealing with various forms of storage, such as conventional electrochemical batteries, hydrogen storage, the wind powered pumped storage systems, compressed air systems as units that can be found in the literature. Systems with battery storage were examined in $[15,16]$. Wind power pumped storage systems were subjected to investigation in [1720], while compressed air systems as storage units were investigated in [21-23].

Dynamic simulation of PV/Wind hybrid energy system located in Belgrade, Serbia was analyzed [24]. The purpose of the study was to design a realistic energy system used for household that maximizes the use of renewable energy and minimizes the use of fossil fuels.

\section{SOLAR AND WIND ENERGY POTENTIAL}

One of the most important data for the application of technologies that use wind and solar energy is properly determination of wind and solar energy potential. The Hydro meteorological Institute of the Republic of Serbia (HMIRS) on the territory of Serbia has 21 meteorological stations that perform continuous measurement of all relevant meteorological data. In recent years, at another location measurements of wind speed and all other relevant weather data were performed. On the basis of these data wind atlas of the Republic of Serbia was made [25]. A solar potential of the Republic of Serbia was also investigated and presented in the paper [26] for the whole territory of Serbia.

In designing systems for the conversion, required data of solar energy is an amount of energy available at a given location in a certain time interval. The amount of solar energy depends on local meteorological conditions, geographical coordinates, orsientation, surface slope, etc. The available solar energy estimations based only on theoretical equations are not sufficient. These influences can be analyzed using data obtained from the long-term measurements. A more precise assessment of available solar energy in the Novi Sad city, Belgrade city and national park Kopaonik are obtained by using the software package Meteonorm. This software uses data on hourly measurements of local weather conditions in different meteorological stations obtained from the Hydro meteorological Institute of the Republic of Serbia. The data of solar radiation are used for further analysis, and for studying the change of the available solar energy due to the inclination and orientation of a given surface.

There are lots of solar databases, NASA - Surface meteorology and solar energy database, RETScreen solar database, PVGIS solar database, European solar radiation atlas, Meteonorm, Solar and wind energy resource assessment (SWERA), etc. In the paper [27] were analyzed solar energy resources from different databases. The results show significant differences in the values of solar energy obtained using a different solar database. In Belgrade annual average values of daily solar radiation per square meter received by the horizontal surface taken from NASA, RETScreen, and PVGIS solar databases are 5.3\%, 2.85\%, and $4.7 \%$ lower, respectively, than the annual average values of daily solar radiation received by the horizontal surface taken from HMIRS. The intensity variation on an hourly basis of the total solar radiation for horizontal surface throughout the typical meteorological year (TMY) for Belgrade is shown on Fig.1. Similar results can be presented for two other sites. The intensity variation on an hourly basis of the total solar radiation of different slope surface throughout the typical meteorological year (TMY) in the Novi Sad city, Belgrade city and national park Kopaonik are shown in Tab.1.

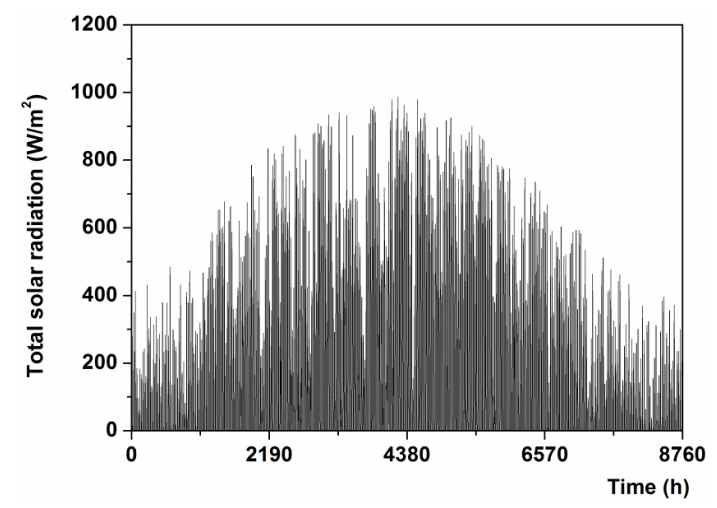

Figure 1. The intensity variations of total solar radiation in Belgrade city

The total solar radiation calculations for whole years, Tab. 1, is shown that the optimal slope of surface is $35^{\circ}$. The dynamic simulations for PV panels were done for this angle. The solar energy available on the sloped surface was used for estimating the amount of electrical energy that can be generated using a PV module.

Table 1. The total solar radiation for typical meteorological year

\begin{tabular}{|c|c|c|c|}
\hline $\begin{array}{c}\text { Slope of } \\
\text { surface }\left({ }^{\circ}\right)\end{array}$ & $\begin{array}{c}\text { Novi Sad } \\
\left(\mathrm{kWh} / \mathrm{m}^{2}\right)\end{array}$ & $\begin{array}{c}\text { Belgrade } \\
\left(\mathrm{kWh} / \mathrm{m}^{2}\right)\end{array}$ & $\begin{array}{c}\text { Kopaonik } \\
\left(\mathrm{kWh} / \mathrm{m}^{2}\right)\end{array}$ \\
\hline $20^{\circ}$ & 1442 & 1501 & 1548 \\
\hline $25^{\circ}$ & 1463 & 1522 & 1574 \\
\hline $30^{\circ}$ & 1475 & 1534 & 1591 \\
\hline $\mathbf{3 5}^{\mathbf{0}}$ & $\mathbf{1 4 7 9}$ & $\mathbf{1 5 3 7}$ & $\mathbf{1 5 9 8}$ \\
\hline $40^{\circ}$ & 1475 & 1531 & 1597 \\
\hline $45^{\circ}$ & 1463 & 1517 & 1586 \\
\hline
\end{tabular}

There is a large selection of PV panels from different manufacturers in the market. In recent years there has been significant progress in the development 
of technologies for the production of cells for PV panels. This development has led to an increase in efficiency. In this paper, PV module SUNPOWERE $20 / 435$ (435W) was selected. This PV module is a 128cell module designed specifically for small and large PV systems and it provides cost-effective power for DC loads or, with an inverter, for AC loads.

The hourly intensity variation of wind speed at 10 $\mathrm{m}$ height above ground in Belgrade for TMY is shown in Fig. 2. Based on measurement at the meteorological stations similar results for Novi Sad and Kopaonik could be presented. The modeling of vertical wind speed distribution above the ground is based on boundary layer theory applied to the atmosphere. Based on this theory, using the equation (1) and wind data sets obtained from a database of meteorological stations, the instantaneous and average wind velocities at different heights in Novi Sad, Belgrade and Kopaonik can be calculated.

$$
\left(\frac{U_{1}}{U_{2}}\right)=\left(\frac{z_{1}}{z_{2}}\right)^{a}
$$

Under ideal boundary layer conditions, the value of $\alpha$ is approximately 0.14 . However, for the actual conditions, value of $\alpha$ is significantly different than 0.14 and depends on a variety of factors and recommended value of factor $\alpha$ is 0.18 .

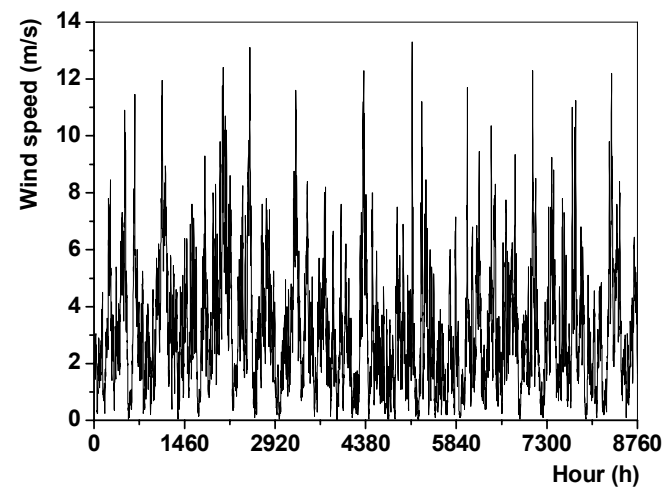

Figure 2. The hourly intensity variation of wind speed for TMY in Belgrade

The wind speed availability for TMY was estimated using the Weibull distribution function. Wind speed is unsteady and it is needed to determine the probability density distribution of the wind speed. This is the distribution of the proportion of time spent by wind within narrow bands of wind speed. An expression which gives a good fit to wind data is known as the Weibull distribution. In non-dimensional form, this distribution can be written as:

$$
p\left(\frac{u}{U}\right)=k \Gamma\left(1+\frac{1}{k}\right)\left\{\frac{u}{U} \Gamma\left(1+\frac{1}{k}\right)\right\}^{k-1} e^{\left\{\frac{u}{U} \Gamma\left(1+\frac{1}{k}\right)\right\}}
$$

where $u$ is the unsteady wind speed component and $U$ is the mean value, $p$ is non-dimensional probability density distribution, $k$ is the shape factor, is the value of the Gamma function. The value of the shape of the curve $k$ is obtained from standard deviation or root mean square of the wind speed:

$$
\frac{\sigma}{U}=\sqrt{\frac{\Gamma\left(1+\frac{1}{k}\right)}{\left[\Gamma\left(1+\frac{1}{k}\right)\right]^{2}}-1}
$$
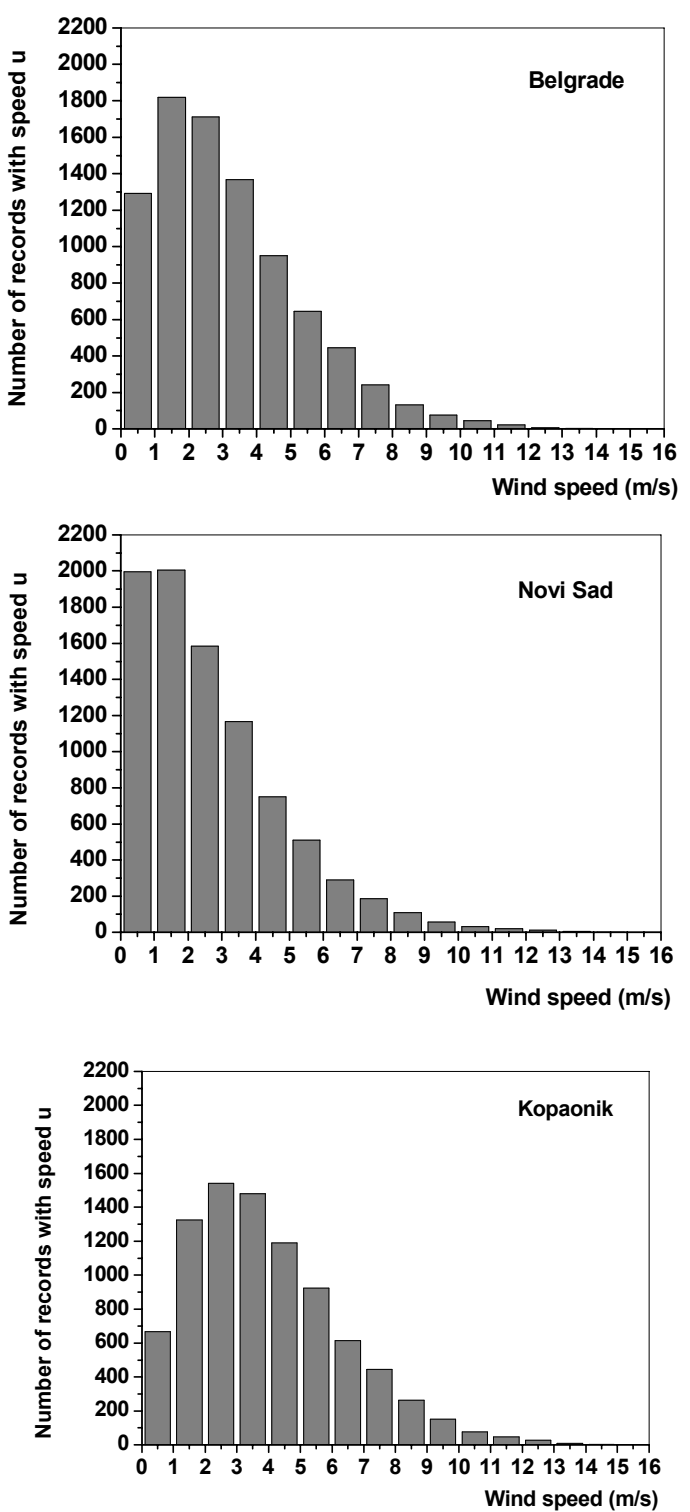

Figure 3. Histogram of hourly wind speeds for Novi Sad, Belgrade and Kopaonik at height $10 \mathrm{~m}$

From simple curve fitting procedure, the shape factor $k$ can be obtained:

$$
k=\left(\frac{0.9874}{\frac{\sigma}{U}}\right)^{1.0983}
$$

and by simple polynomial fit Gamma function can be calculated. In Tab.2 the statistical wind characteristics obtained from the typical meteorological year for Novi Sad, Belgrade and Kopaonik national park are shown.

The power curves for different wind turbines are shown in Fig. 4. These curves are obtained from manufacturers of wind turbines and present the amount of power that can be achieved for different wind speed. 
Table 2. The statistical wind characteristics for TMY.

\begin{tabular}{|c|c|c|c|c|c|c|c|c|c|c|}
\hline \multirow{3}{*}{\multicolumn{2}{|c|}{$\begin{array}{l}\text { coefficients of Weibull } \\
\text { distribution at } 10 \mathrm{~m} \text { height }\end{array}$}} & \multicolumn{3}{|c|}{ Novi Sad } & \multicolumn{3}{|c|}{ Belgrade } & \multicolumn{3}{|c|}{ Kopaonik } \\
\hline & & $\sigma / U$ & $k$ & $\Gamma$ & $\sigma / U$ & $k$ & $\Gamma$ & $\sigma / U$ & $k$ & $\Gamma$ \\
\hline & & 2.131 & 1.265 & 0.930 & 2.160 & 1.480 & 0.908 & 2.385 & 1.700 & 0.893 \\
\hline \multirow{4}{*}{$\begin{array}{c}\text { Mean wind } \\
\text { speed } \\
(\mathrm{m} / \mathrm{s})\end{array}$} & $10 \mathrm{~m}$ & \multicolumn{3}{|c|}{2.675} & \multicolumn{3}{|c|}{3.130} & \multicolumn{3}{|c|}{3.922} \\
\hline & $20 \mathrm{~m}$ & \multicolumn{3}{|c|}{3.031} & \multicolumn{3}{|c|}{3.457} & \multicolumn{3}{|c|}{4.444} \\
\hline & $30 \mathrm{~m}$ & \multicolumn{3}{|c|}{3.260} & \multicolumn{3}{|c|}{3.816} & \multicolumn{3}{|c|}{4.781} \\
\hline & $40 \mathrm{~m}$ & \multicolumn{3}{|c|}{3.433} & \multicolumn{3}{|c|}{4.017} & \multicolumn{3}{|c|}{5.034} \\
\hline
\end{tabular}

The characteristics of wind turbines are used in the transient dynamic simulations of considered energy systems. According to the manufacturers' recommendations, the wind turbine tower has to be higher than $18 \mathrm{~m}$.

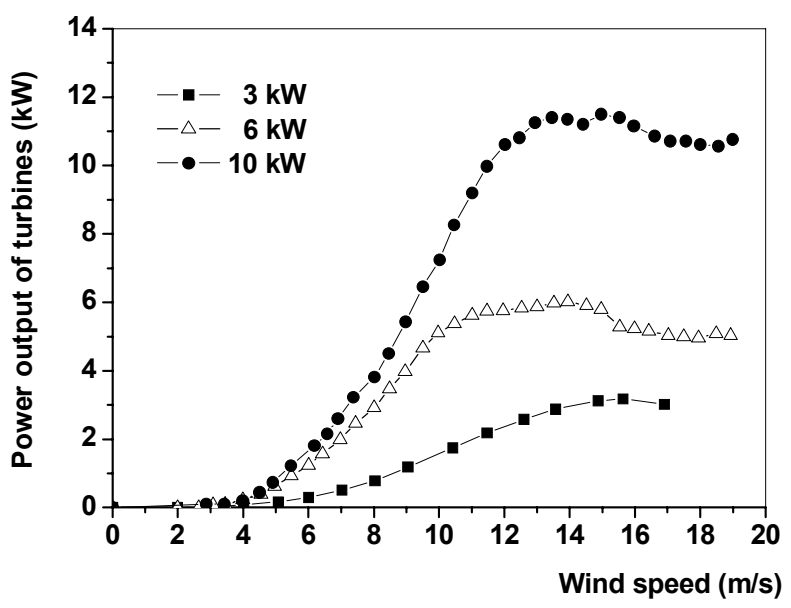

Figure 4. Power curves for different wind turbines.

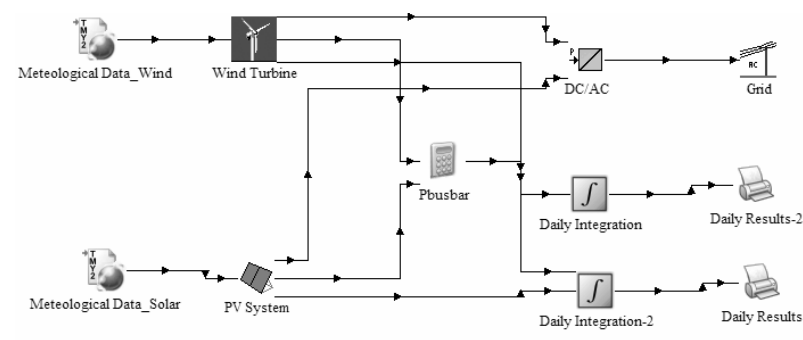

Figure 5. Scheme of the grid-connected PV/Wind hybrid energy station.

\section{MODEL OF DYNAMIC SIMULATION AND RESULTS}

The illustration of grid-connected PV/Wind hybrid energy station for the production of electrical power is shown in Fig. 5. All the components of the combined system are modeled with appropriate mathematical models expressed by differential and algebraic equations. The results of the simultaneous solution of these equations are the hourly change of all physical properties that characterize the energy system. Type 94, 5-parameter model for PV arrays and Type 90 model of the wind energy conversion station for the wind turbine were selected for this analysis. The hybrid energy systems operate without energy storage and it is connected to the grid through a bi-directional inverter. The energy system will disconnect from the grid and operate as a stand alone-alone system due to grid faults or similar reasons.

\subsection{Mathematical model of hybrid PV/Wind systems}

A renewable $\mathrm{PV} / \mathrm{Wind}$ energy system consists of wind turbine generator, a photovoltaic array as primary energy source and different power electronic interfaces for control and voltage adaptation purpose.

\subsubsection{Photovoltaic array}

The solar array is a group of several modules electrically connected in series parallel combinations to generate the required current and voltage.

The current-voltage equation for this 5-parameters model is:

$$
I=I_{\mathrm{L}}-I_{0}\left[\exp \left(\frac{q}{\gamma k T_{\mathrm{c}}}\left(V+I R_{\mathrm{S}}\right)\right)-1\right]-\frac{V+I R_{\mathrm{S}}}{R_{\mathrm{sh}}}
$$

where are: $I$ current, $I_{\mathrm{L}}$ module photocurrent, $I_{\mathrm{o}}$ diode reverse saturation current, $q$ electron charge constant, $\gamma$ empirical PV curve-fitting parameter, $k$ Boltzmann constant, $T_{\mathrm{c}}$ module temperature, $V$ voltage, $R_{\mathrm{s}}$ module series resistance and $R_{\mathrm{sh}}$ module shunt resistance. The addition to this circuit element changes the equations used to find the other values from available manufacturers' data.

The shunt resistance can be approximated by:

$$
R_{\mathrm{sh}} \approx-\frac{1}{\left(\frac{d I}{d V}\right)_{\mathrm{V}-0}}
$$

The maximum power conditions yield the following expressions for $I_{\mathrm{L}, \text { ref }}, I_{\mathrm{o}, \mathrm{ref}}, \gamma$.

$$
\begin{aligned}
& I_{\mathrm{L}, \text { ref }}=I_{\mathrm{sc}, \mathrm{ref}}\left(1+\frac{R_{\mathrm{S}}}{R_{\mathrm{sh}}}\right) \\
& I_{0, \text { ref }}=\frac{I_{\mathrm{L}, \text { ref }}-\frac{V_{0 \mathrm{c}, \text { ref }}}{R_{\mathrm{sh}}}}{\exp \left(\frac{q}{k \gamma T_{\mathrm{c}, \text { ref }}}-V_{0 \mathrm{c}, \text { ref }}\right)} \\
& \gamma=\frac{q\left(V_{\mathrm{mp}, \text { ref }}-V_{0 \mathrm{c}, \text { ref }} R_{\mathrm{s}}+I_{\mathrm{mp}, \text { ref }} R_{\mathrm{s}}\right)}{k T_{\mathrm{c}, \text { ref }} \ln \left(\frac{I_{\mathrm{L}, \text { ref }}-I_{\mathrm{mp}, \text { ref }}-\frac{V_{\mathrm{mp}, \text { ref }}+I_{\mathrm{mp}, \text { ref }} R_{\mathrm{s}}}{R_{\mathrm{sh}}}}{I_{\mathrm{sc}, \text { ref }}-\frac{V_{0 \mathrm{c}, \text { ref }}}{R_{\mathrm{sh}}}}\right)}
\end{aligned}
$$

Where are: $I_{\mathrm{L}, \mathrm{ref}}$ module photocurrent at reference conditions, $I_{\text {sc,ref }}$ short-circuit current at reference conditions, $I_{\mathrm{o} \text {,ref }}$ diode reverse saturation current at reference conditions, $V_{\text {oc,ref }}$ open-circuit voltage at 
reference conditions, $I_{\mathrm{mp}, \mathrm{ref}}$ current at maximum power point along $I V$ curve at reference conditions and $V_{\text {mp,ref }}$ voltage at maximum power point along $I V$ curve at reference conditions. An iterative routine is used to find the correct values for $R_{\mathrm{s}}$ and $\gamma$ by matching the analytical value for $\mu_{\mathrm{voc}}$ to that given in the catalog.

The temperature of cells in each time step is determined by using temperature cell for nominal operating cell temperature conditions:

$$
T_{\mathrm{c}}=T_{\mathrm{a}}+\frac{\left(1-\frac{\eta_{\mathrm{c}}}{\tau \alpha}\right)}{\left(\frac{G_{\mathrm{T}} \tau \alpha}{U_{\mathrm{L}}}\right)}
$$

where are $U_{\mathrm{L}}$ array thermal loss coefficient, $G_{\mathrm{T}}$ total radiation incident on $\mathrm{PV}$ array, $T_{\mathrm{a}}$ ambient temperature and $\tau \alpha$ may be either a constant or it may be calculated by using:

$$
\frac{\tau \alpha}{U_{\mathrm{L}}}=\frac{\left(T_{\mathrm{c}, \mathrm{NOCT}}-T_{\mathrm{a}, \mathrm{NOCT}}\right)}{G_{\mathrm{T}, \mathrm{NOCT}}}
$$

Incidence angle modifier determines the transmittancereflectance product $(\tau \alpha)$ of the module of each time step. The expression for the incidence angle modifier is:

$$
\begin{gathered}
I A M=1-\left(1.098 \times 10^{-4}\right) \theta-\left(6.267 \times 10^{-6}\right) \theta^{2} \\
+\left(6.583 \times 10^{-7}\right) \theta^{3}-\left(1.4272 \times 10^{-8}\right) \theta^{4} \\
I A M=\frac{\tau \alpha}{\tau \alpha_{\text {normal }}}
\end{gathered}
$$

$\tau \alpha$ At normal incidence is not usually included in the list of manufacturer's parameters, although 0.9 is usually a good estimate.

Photovoltaic panels operate over a large range of climatic conditions, so the manufacturer's data for PV panels is not sufficient to determine their overall performance. The manufacturers usually provide only limited operational data, such as the short circuit current $\left(I_{\mathrm{sc}}\right)$, the open circuit voltage $\left(V_{\mathrm{oc}}\right)$, the maximum power current $\left(I_{\mathrm{mp}}\right)$ and voltage $\left(V_{\mathrm{mp}}\right)$, the temperature coefficients at open circuit voltage and short circuit current $\left(\beta_{\mathrm{Voc}}\right.$ and $\alpha_{\mathrm{Isc}}$, respectively), and the nominal operating cell temperature (NOCT). These data are available only at standard rating conditions (SRC), for which the irradiance is $1000 \mathrm{~W} / \mathrm{m}^{2}$ and the cell temperature $\left(T_{\mathrm{c}}\right)$ is $25{ }^{\circ} \mathrm{C}$ (except for the NOCT which is determined at $800 \mathrm{~W} / \mathrm{m}^{2}$ and an ambient temperature of $20{ }^{\circ} \mathrm{C}$ ). This is a reason why it is still essential to work on the validation and improvement of 5-parameters model for PV panels for each working condition of operative temperature and solar irradiance [28-30].

The software package TRNSYS simultaneously solves the system of equations (mathematical models of components of energy system) in the time domain. Since the problem is unsteady, the time step is chosen to be 0.05 hours. Further decrease of time step does not effect on simulation results. Tolerance convergence and tolerance integration are 0.0001 . The PV convergence promotion algorithm of input parameters was set to any nonzero value, according to recommendation of software manufactures.

\subsubsection{Wind turbine}

The wind energy that can be converted into usable energy (electrical power) was determined using the power equation, which includes the efficiency of the wind turbines at different wind speeds. The wind turbine rotor that extracts the energy from the wind and converts it into mechanical power is a complex aerodynamic system. Modeling the rotor using blade element theory has a number of limitations: an array of wind speed signals must be applied, detailed information about the rotor geometry should be available and computation becomes complicated and lengthy.

To overcome these difficulties, a simplified way of modeling the wind turbine is normally used when the electrical behavior of the system is the main point of interest. An algebraic relation between wind speed and mechanical power extracted is assumed, which is described by the well-known expression:

$$
P_{\mathrm{w}}=C_{\mathrm{p}} \rho A_{\mathrm{R}} U_{0}^{3}
$$

where are: $C_{\mathrm{p}}$ power coefficient, $\rho$ air density, $A_{\mathrm{R}}$ blade area and $U_{\mathrm{o}}$ wind speed. Power coefficient, $C_{\mathrm{p}}$ is a function of the wind velocity and it is different for each wind turbine.

\section{RESULTS OF DYNAMIC SIMULATIONS}

Hybrid energy stations can consist of any combination of wind turbine, photovoltaic panels and additional equipment. Such flexibility has obvious advantages in customizing a system to a particular site's energy resource, costs, and load requirements. In the present case, a different combination PV/wind hybrid energy station and a power converter are used to design. The dynamic simulations for a PV/Wind energy station with 10,15 and $20 \mathrm{PV}$ modules and with $3 \mathrm{~kW}, 6 \mathrm{~kW}$ and 10 $\mathrm{kW}$ wind turbines have been done. As a result of dynamic simulations an hourly change of electrical power output of the observed energy station was obtained. The hourly change of power output through the year of energy system with the 20 PV modules (each module with nominal power of $435 \mathrm{~W}$ ) and the $10 \mathrm{~kW}$ wind turbine with $30 \mathrm{~m}$ tower energy system for national park Kopaonik is shown in Fig. 6 and Fig.7. Similar results can be presented for Novi Sad and

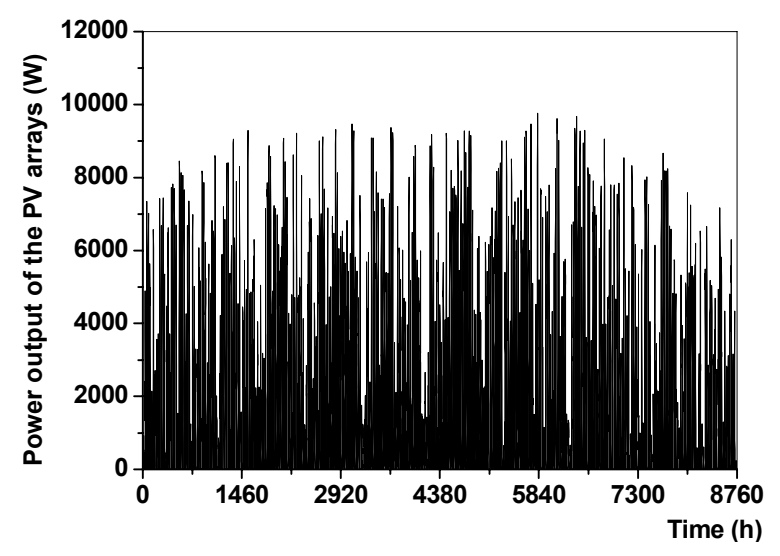

Figure 6. Power output of the PV arrays (20 modules) at the location Kopaonik. 


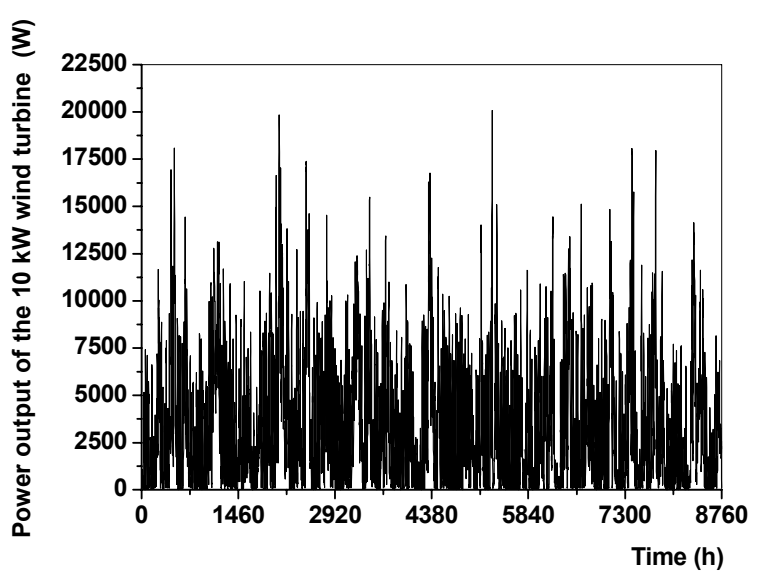

Figure 7. Power output of the $10 \mathrm{~kW}$ wind turbine at the location Kopaonik.

Belgrade. Figure 8 shows the changes in the generated electrical power with a change in the number of PV panels in all three locations. Wind speeds increase at higher altitudes due to surface aerodynamic drag and the viscosity of the air. In the daytime the variation follows the wind profile power law. Increasing the altitude of a turbine increases the wind speeds and the wind power. In this paper, influence the different heights of the wind turbines towers, on production of the wind turbines electrical power were analyzed. This influence is shown in Fig. 9.

The obtained electrical energy from various configurations of $\mathrm{PV} /$ wind energy systems for the regions of Novi Sad, Belgrade cities, and national park Kopaonik are shown in Tab. 3, Tab. 4 and Tab. 5.

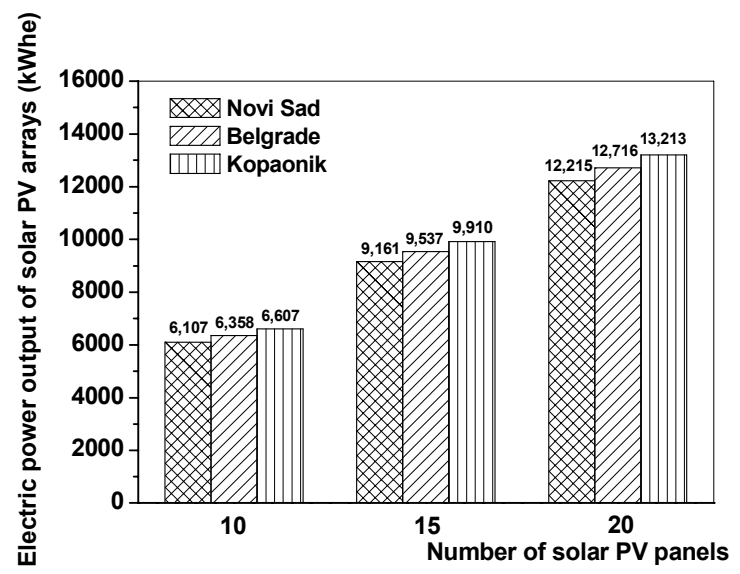

Figure 8. Relation between electrical power output and the number of PV panels for three locations in Serbia

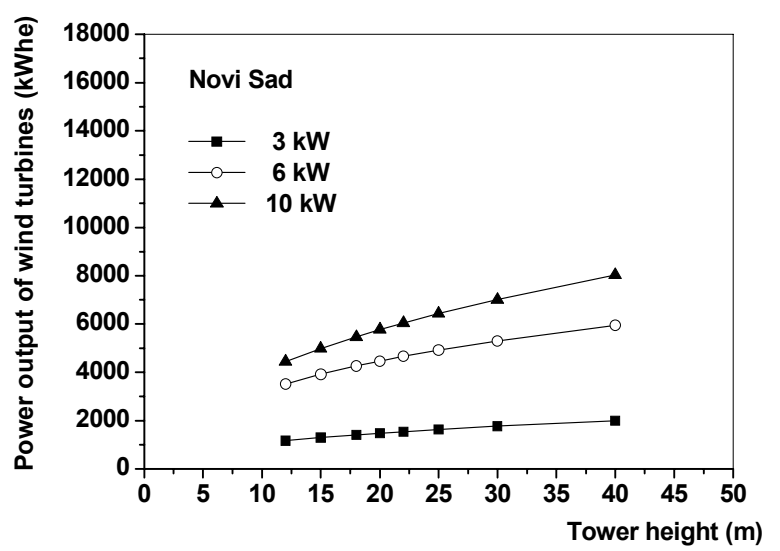

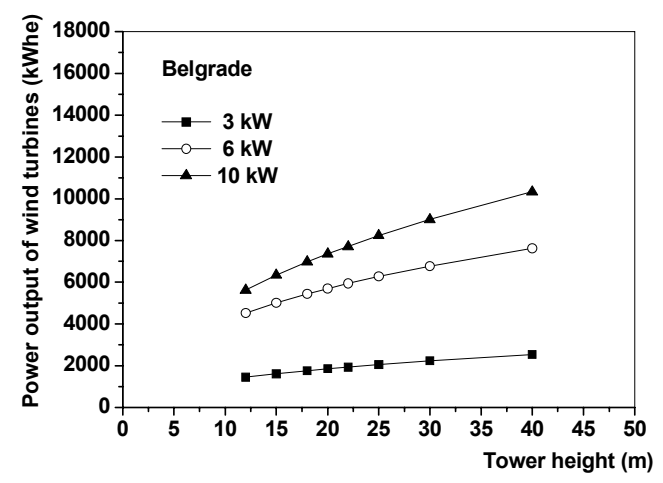

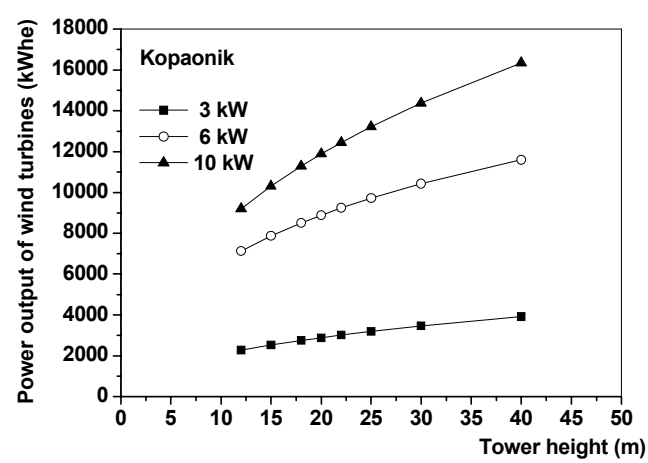

Figure 9. An influence of turbine towers height on the electrical power output productions

These three locations were selected from the north of the Republic of Serbia, Novi Sad to the south, national park Kopaonik. Kopaonik is one of the highest mountains in Serbia. It is located in the central part of Serbia. Meteorological station is situated at longitude $20^{\circ} 48 \mathrm{E}$, latitude $43^{\circ} 17 \mathrm{~N}$ and $1710 \mathrm{~m}$ above sea level. Kopaonik has over 200 sunny days annually. Belgrade is the capital, situated at longitude $20^{\circ} 28 \mathrm{E}$, latitude $44^{\circ} 48 \mathrm{~N}$ and $132 \mathrm{~m}$ above sea level. The average annual number of sunny hours is 2,112. Novi Sad is located southern part of Pannonian Plain, on the border of the Bačka and Srem regions, at longitude $19^{\circ} 51 \mathrm{E}$, latitude $45^{\circ} 20 \mathrm{~N}$ and $84 \mathrm{~m}$ above sea level. Novi Sad has a temperate continental climate, with four seasons and 2,135 sunny hours per year.

\subsection{Greenhouse gas reduction}

According to the Kyoto protocol, greenhouse gases (GHG) cover six categories of gases $\left(\mathrm{CO}_{2}, \mathrm{CH}_{4}, \mathrm{~N}_{2} \mathrm{O}\right.$ $\left.\mathrm{HFC}, \mathrm{PFC}, \mathrm{SF}_{6}\right)$ and is estimated using the $\mathrm{CO}_{2}$ equivalent $\left(\mathrm{CO}_{2 \mathrm{eq}}\right)$, a metric used to compare the emissions from various greenhouse gases based upon their global warming potential. Serbia as a developing country (Non Annex I Party) has committed to the international co-operation in the field of climate research with the obligation of reporting National Communications to the UNFCCC, but without obligations to reduce GHG emission. Based on positive example it is clear that Serbia as a candidate for the EU membership will have much to improve its capacity (to prepare legislation and institutions) for the full implementation of the EU energy-climate package including implementation of the ETS Directive 2009/29/EC (Directive 2009/29/EC of the European Parliament and of the Council amending Directive 2009/ 
Table 3.Electrical power of the PV/Wind energy system with $3 \mathrm{~kW}$ wind turbine and different numbers of PV modules

\begin{tabular}{|c|c|c|c|c|c|c|c|c|c|c|}
\hline \multirow{3}{*}{\multicolumn{2}{|c|}{$\begin{array}{l}3 \mathrm{~kW} \\
\text { wind turbine }\end{array}$}} & \multicolumn{3}{|c|}{$\begin{array}{l}\text { Novi Sad } \\
\left(\mathrm{kWh}_{\mathrm{e}}\right)\end{array}$} & \multicolumn{3}{|c|}{$\begin{array}{l}\text { Belgrade } \\
\left(\mathrm{kWh}_{\mathrm{e}}\right)\end{array}$} & \multicolumn{3}{|c|}{$\begin{array}{l}\text { Kopaonik } \\
\left(\mathrm{kWh}_{\mathrm{e}}\right)\end{array}$} \\
\hline & & \multicolumn{3}{|c|}{ number of PV module } & \multicolumn{3}{|c|}{ number of PV module } & \multicolumn{3}{|c|}{ number of PV module } \\
\hline & & 10 & 15 & 20 & 10 & 15 & 20 & 10 & 15 & 20 \\
\hline \multirow{4}{*}{$\begin{array}{l}\text { wind turbine } \\
\text { tower height }\end{array}$} & $12 \mathrm{~m}$ & 7,107 & 10,329 & 13,383 & 7,811 & 10,990 & 14,169 & 8,889 & 12,192 & 15,496 \\
\hline & $20 \mathrm{~m}$ & 7,579 & 10,633 & 13,687 & 8,207 & 11,386 & 14,565 & 9,498 & 12,801 & 16,104 \\
\hline & $30 \mathrm{~m}$ & 7,873 & 10,927 & 13,981 & 8,587 & 11,766 & 14,945 & 10,073 & 13,376 & 16,679 \\
\hline & $40 \mathrm{~m}$ & 8,110 & 11,164 & 14,215 & 8,894 & 12,073 & 15,252 & 10,530 & 13,833 & 17,136 \\
\hline
\end{tabular}

Table 4. Electrical power of the PV/Wind energy system with $6 \mathrm{~kW}$ wind turbine and different numbers of PV modules

\begin{tabular}{|c|c|c|c|c|c|c|c|c|c|c|}
\hline \multirow{3}{*}{\multicolumn{2}{|c|}{$\begin{array}{l}6 \mathrm{~kW} \\
\text { wind turbine }\end{array}$}} & \multicolumn{3}{|c|}{$\begin{array}{l}\text { Novi Sad } \\
\left(\mathrm{kWh}_{\mathrm{e}}\right)\end{array}$} & \multicolumn{3}{|c|}{$\begin{array}{l}\text { Belgrade } \\
\left(\mathrm{kWh}_{\mathrm{e}}\right)\end{array}$} & \multicolumn{3}{|c|}{$\begin{array}{l}\text { Kopaonik } \\
\left(\mathrm{kWh}_{\mathrm{e}}\right)\end{array}$} \\
\hline & & \multicolumn{3}{|c|}{ number of PV module } & \multicolumn{3}{|c|}{ number of PV module } & \multicolumn{3}{|c|}{ number of PV module } \\
\hline & & 10 & 15 & 20 & 10 & 15 & 20 & 10 & 15 & 20 \\
\hline \multirow{4}{*}{$\begin{array}{l}\text { wind turbine } \\
\text { tower height }\end{array}$} & $12 \mathrm{~m}$ & 9,625 & 12,679 & 15,733 & 10,891 & 14,070 & 17,249 & 13,742 & 17,045 & 20,348 \\
\hline & $20 \mathrm{~m}$ & 10,576 & 13,630 & 16,684 & 12,057 & 15,236 & 18,415 & 15,498 & 18,801 & 22,104 \\
\hline & $30 \mathrm{~m}$ & 11,408 & 14,462 & 17,516 & 13,133 & 16,312 & 19,491 & 17,039 & 20,432 & 23,645 \\
\hline & $40 \mathrm{~m}$ & 12,054 & 15,108 & 18,162 & 13,986 & 17,165 & 20,344 & 18,207 & 21,510 & 24,813 \\
\hline
\end{tabular}

Table 5. Electrical power of the PV/Wind energy system with 10kW wind turbine and different numbers of PV modules

\begin{tabular}{|c|c|c|c|c|c|c|c|c|c|c|}
\hline \multirow{3}{*}{\multicolumn{2}{|c|}{$\begin{array}{l}10 \mathrm{~kW} \\
\text { wind turbine }\end{array}$}} & \multicolumn{3}{|c|}{$\begin{array}{l}\text { Novi Sad } \\
\left(\mathrm{kWh}_{\mathrm{e}}\right)\end{array}$} & \multicolumn{3}{|c|}{$\begin{array}{l}\text { Belgrade } \\
\left(\mathrm{kWh}_{\mathrm{e}}\right)\end{array}$} & \multicolumn{3}{|c|}{$\begin{array}{l}\text { Kopaonik } \\
\left(\mathrm{kWh}_{\mathrm{e}}\right)\end{array}$} \\
\hline & & \multicolumn{3}{|c|}{ number of PV module } & \multicolumn{3}{|c|}{ number of PV module } & \multicolumn{3}{|c|}{ number of PV module } \\
\hline & & 10 & 15 & 20 & 10 & 15 & 20 & 10 & 15 & 20 \\
\hline \multirow{4}{*}{$\begin{array}{l}\text { wind turbine } \\
\text { tower height }\end{array}$} & $12 \mathrm{~m}$ & 10,552 & 13,606 & 16,660 & 12,233 & 15,163 & 18,342 & 15,810 & 19,113 & 22,416 \\
\hline & $20 \mathrm{~m}$ & 11,874 & 14,928 & 17,982 & 13,717 & 16,896 & 20,075 & 18,493 & 21,796 & 25,099 \\
\hline & $30 \mathrm{~m}$ & 13,127 & 16,181 & 19,235 & 15,368 & 18,547 & 21,726 & 20,984 & 24,287 & 27,590 \\
\hline & $40 \mathrm{~m}$ & 14,144 & 17,198 & 20,252 & 16,689 & 19,868 & 23,047 & 22,949 & 26,252 & 29,555 \\
\hline
\end{tabular}

their global warming potential. Serbia as a developing country (Non Annex I Party) has committed to the international co-operation in the field of climate research with the obligation of reporting National Communications to the UNFCCC, but without obligations to reduce GHG emission. Based on positive example it is clear that Serbia as a candidate for the EU membership will have much to improve its capacity (to prepare legislation and institutions) for the full implementation of the EU energy-climate package including implementation of the ETS Directive 2009/29/EC (Directive 2009/29/EC of the European Parliament and of the Council amending Directive 2003/87/EC so as to improve and extend the greenhouse gas emission allowance trading scheme of the Community).

Low calorific, open-pit mined lignite is the basic energy source of the Republic of Serbia for production electrical power, with a share of nearly $50 \%$ in the total primary energy consumption and over $70 \%$ in the power generation. Emissions of $\mathrm{CO}_{2}$ from lignite combustion have a dominant share of more than $40 \%$ in total emission of GHG in Serbia. In Serbia, low quality raw lignite, with average net calorific value about 7.850 $\mathrm{MJ} / \mathrm{kg}$ has a much higher carbon emission factor of CEF $=29.78 \mathrm{tC} / \mathrm{TJ}\left(1.282 \mathrm{kgCO}_{2} / \mathrm{kWh}_{\mathrm{e}}\right)$ [31] compared to the recommended value for lignite of $\mathrm{CEF}=27.6 \mathrm{tC} / \mathrm{TJ}$ according to IPCC.

In Tab. 6 the possible annual reductions of direct $\mathrm{CO}_{2}$ emissions for some considered systems are shown.
Table 6. Direct $\mathrm{CO}_{2}$ emissions reduction (wind turbine tower height $\mathbf{3 0} \mathrm{m}$ )

\begin{tabular}{|l|c|c|c|}
\hline & $\begin{array}{c}20 \mathrm{PV} \\
\text { modules }+3 \\
\mathrm{~kW} \text { wind } \\
\text { turbine } \\
\left(\mathrm{tCO}_{2}\right)\end{array}$ & $\begin{array}{c}20 \mathrm{PV} \\
\text { modules }+6 \\
\mathrm{~kW} \text { wind } \\
\text { turbine } \\
\left(\mathrm{tCO}_{2}\right)\end{array}$ & $\begin{array}{c}20 \mathrm{PV} \\
\text { modules } \\
10 \mathrm{~kW} \\
\text { wind } \\
\text { turbine } \\
\left(\mathrm{tCO}_{2}\right)\end{array}$ \\
\hline Novi Sad & 17.92 & 22.46 & 24.66 \\
\hline Belgrade & 19.16 & 24.99 & 27.85 \\
\hline Kopaonik & 21.38 & 30.31 & 35.37 \\
\hline
\end{tabular}

\section{ECONOMIC ANALYSIS}

\subsection{Feed-in tariffs in Serbia}

By the ratification of the Treaty establishing the Energy Community, the Republic of Serbia accepted the obligation to adopt and implement the plan of the Directive 2001/77/EC for the promotion of renewable energy sources for electricity production and the 2003/30/EC Directive on the promotion of the use of biofuels and other renewable fuels for transport. On 26th January, 2009, the Republic of Serbia became a member and founder of the International Renewable Energy Agency (IRENA) as the first international (inter-Governmental) organization that focuses solely on renewable energy and will actively continue its participation in the work of this Agency in accordance with the Agency Statute and its own interests in the field of activating and consuming of renewable energy sources. 
In 2012 the Serbian Government adopted a Decree on the Requirements for obtaining the Status of the Privileged Power Producer and the Criteria for Assessing Fulfillments of these Requirements ("Official Gazette RS", No. 8/13). This document provided as Feed-in tariffs expressed in euro-cents per kilowatt hour $(\mathrm{c} € / \mathrm{kWh})$ according to the type of power plant producing electricity from renewable energy sources and the capacity installed (P), stated in MW are presented in Tab.7. These benefits of using renewable energy sources are valid until the end of 2015.

Table 7. Feed-in tariffs expressed in euro-cents per kilowatt hour $\left(\mathbf{c} \$ / k W h_{e}\right)$

\begin{tabular}{|l|l|c|}
\hline \multirow{2}{*}{$\begin{array}{l}\text { Type of power } \\
\text { plants }\end{array}$} & Installed capacity & $\begin{array}{l}\text { Encouraging } \\
\text { measures } \\
\text { Feed-in tariff }\end{array}$ \\
\cline { 2 - 3 } & $\mathrm{MW}$ & $\mathrm{c \$} / \mathrm{kWh}$ \\
\hline Wind power plants & & 9.20 \\
\hline \multirow{3}{*}{ Solar power plants } & $\begin{array}{l}\text { on the roof up to } \\
0.03\end{array}$ & \begin{tabular}{l}
20.66 \\
\cline { 2 - 3 }
\end{tabular} \\
\cline { 2 - 3 } & $\begin{array}{l}\text { on the roof from } \\
\text { o.03 to } 0.5\end{array}$ & $20.941-9.383 \cdot \mathrm{P}$ \\
\cline { 2 - 3 } & on the ground & 16.25 \\
\hline
\end{tabular}

*P stands for installed capacity

\subsection{Result of economic analysis}

The main objective of the economic analysis is to determine the interrelation of technical, climatic and economic parameters. This analysis can be done only on a case-by-case basis. In this paper, the number of cases analyzed was 27 . It is known that similar hybrid systems are not cost effective due to the relatively high cost of PV modules and wind generators. Fortunately, in recent years, prices have fallen to an acceptable level. In Tab. 8 are given the economic costs of equipment that were used in the economic analysis.

Table 8. Input economic costs

\begin{tabular}{|l|l|l|l|}
\hline & $\begin{array}{l}\text { Capital } \\
\text { cost } \\
\$ / \mathrm{kW}\end{array}$ & $\begin{array}{l}\text { Replacement } \\
\text { cost } \\
\$ / \mathrm{kW}\end{array}$ & $\begin{array}{l}\text { Operating and } \\
\text { maintenance } \\
\text { cost } \\
\$ /(\mathrm{yr} \mathrm{kW})\end{array}$ \\
\hline $\begin{array}{l}\text { PV } \\
\text { modules }\end{array}$ & 2,200 & 1,980 & 22 \\
\hline $\begin{array}{l}\text { Wind } \\
\text { turbines }\end{array}$ & 2,500 & 2,250 & 50 \\
\hline Inverters & 400 & 400 & 0 \\
\hline
\end{tabular}

Other economic parameters used in this economic analysis are: annual real interest rate $6 \%$, project lifetime of 20 years, system fixed capital costs (permitting, environment study, grid interconnection: 1600 \$, fixed + engineering: 500 \$, fixed) 2100 \$, system fixed operation and maintenance $0 \$ / y r$.

The capacity factor (CF) is the ratio of the system's predicted electrical output in the first year of operation to the nameplate output. That is equivalent to the quantity of energy the system would generate if it operates at its nameplate capacity for every hour of the year. This parameter depends on the technical characteristics of PV modules and wind turbines, as well as the climatic parameters (global solar radiation, temperature and wind speed). In the Fig. 10 is shown the capacity factor for the typical cases, Tab. 7. The capacity factor for the PV array is the same for all three locations, while it is different for wind turbines. In other words, electrical power generated by the wind turbines is different for different power of wind turbines, but also it depends on where it is located (Kopaonik, Belgrade and Novi Sad).

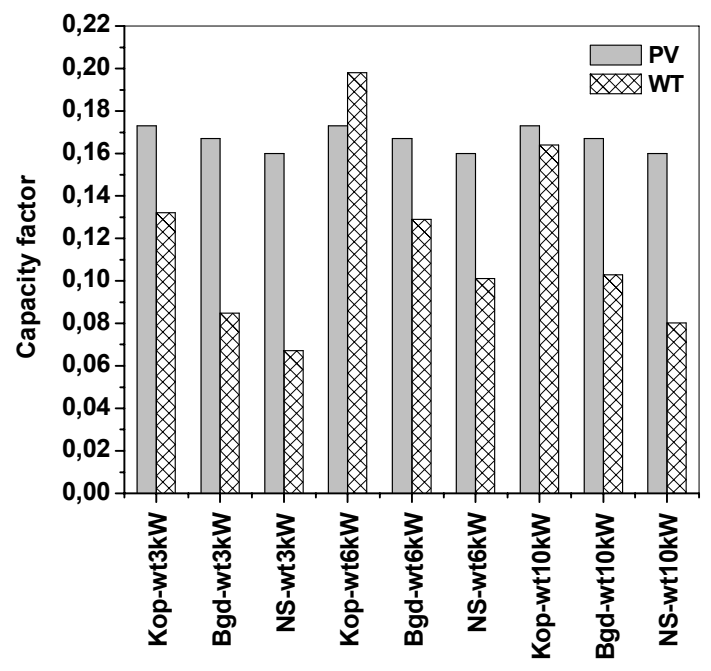

Figure 10. Capacity factor for wind turbines tower height of 30 m. (Kop - Kopaonik, Bgd - Belgrade, NS - Novi Sad)

Fig. 10 shows that the capacity utilization of PV modules is better than wind turbines, except for Kopaonik, in the case of wind turbine with power of 6 $\mathrm{kW}$. The CF for PV module varies relatively little (Kopaonik 100\%, Belgrade: $96.5 \%$ and Novi Sad: $92.5 \%$ ), while the difference for wind turbines is significantly higher and varies from location. Small CF for wind turbine indicates inadequate choice of type of turbine.

The Levelized Cost of Energy (LCOE) is the total cost of installing and operating a project expressed in $\$ / \mathrm{kWh}_{\mathrm{e}}$ of electrical power generated by the system over its life [37]. LCOE is recommended for use when ranking alternatives given a limited budget simply because the measure will provide a proper ordering of the alternatives, which is described by the well-known expression:

$$
L C O E=\frac{T L C C}{\sum_{\mathrm{n}=1}^{\mathrm{N}} \frac{Q_{\mathrm{n}}}{(1+d)^{\mathrm{n}}}}=\frac{\sum_{\mathrm{n}=0}^{\mathrm{N}} \frac{C_{\mathrm{n}}}{(1+d)^{\mathrm{n}}}}{\sum_{n=1}^{N} \frac{Q_{\mathrm{n}}}{(1+d)^{\mathrm{n}}}}
$$

where are: TLCC total life-cycle cost, $C_{\mathrm{n}}$ cost in period $\mathrm{n}, Q_{\mathrm{n}}$ energy output or saved in year $\mathrm{n}$, $\mathrm{d}$ annual discount rate, $\mathrm{N}$ analysis period.

Levelized cost of energy is the cost, which does not take into account income from sales of electrical energy. If it is anticipated that the system of all electrical energy sales to operator, as assumed in this work, and we want the system to be economically viable, it is necessary that electrical energy is sold at a price that is higher than the LCOE. In this paper we discuss two cases: first, when the prices of electrical energy from the PV module and the wind turbine (WT) are the same $\left(28.71 \mathrm{c} \$ / \mathrm{kWh}_{\mathrm{e}}-\right.$ "Privileged price"), and second when the prices are 
different, (28.71 c\$/kWh $\mathrm{k}_{\mathrm{e}}$ and $12.88 \mathrm{c} \$ / \mathrm{kWh}_{\mathrm{e}}-$ "Mixed price"). These rates correspond to Feed-in tariffs from Tab. 8. The main problem is that the Serbian legislature anticipated cost electrical power from the wind turbine, which relates to big wind power plants, rather than to run the wind turbine as part of the hybrid system. Therefore, the price of $12.88 \mathrm{c} \$ / \mathrm{kWh}_{\mathrm{e}}$ for electrical power from wind turbines is unrealistically small for small wind turbines.

For an economic analysis of hybrid systems with different prices for electrical power from PV modules and wind turbines, a convenient way of calculating the Cost of energy (COE) is defined in [32]. The annualized cost of producing energy is divided by the total electric load served during one year. Therefore, the benchmark price to determine whether the system is economically justified is $0 \mathrm{c} \$ / \mathrm{kWh}_{\mathrm{e}}$. For that price, the costs are equal to sales, and if the "Cost of Energy" is negative, the system is cost effective. The Fig. 11 shows the cost of energy (COE), calculated using HOMER software with wind turbine tower height of $30 \mathrm{~m}$.

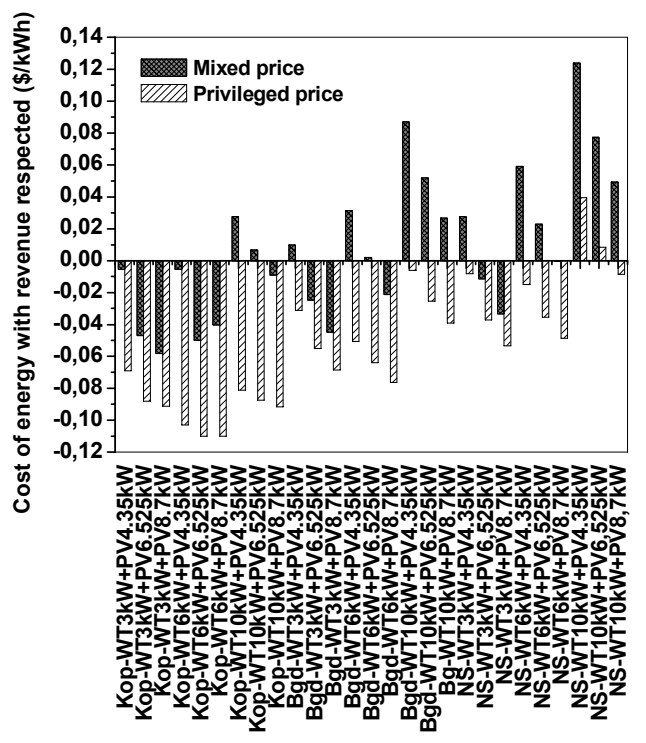

Figure 11. Cost of energy (wind turbine tower height $30 \mathrm{~m}$ )

The Fig. 11 shows that the systems with price for electrical power generation of $28.71 \mathrm{c} \$ / \mathrm{kWh}$ in almost all cases, have negative values of COE. In the case of different prices for electric power from PV modules and wind turbine costs for most of the considered energy systems are greater than the income, which means the system is considered not cost effective. It can be concluded that, if we want to increase usage of hybrid wind-solar systems, privileged price must be valid for both types of sources, not only for PV modules.

In the following analyzes, only systems with a high unique privileged price $\left(28.71 \mathrm{c} \$ / \mathrm{kWh}_{\mathrm{e}}\right.$ are discussed. On Fig. 12 is shown the Levelized cost of energy LCOE calculated using equation (15). The Fig. 12 provides the ranking of the considered energy systems in terms of the price of a kilowatt-hour. Economical feasibility are the cases for LCOE less than 0.287 \$/kWh. Lowest price kilowatt-hour is for the case Kopaonik WT $6 \mathrm{~kW}$ and PV $8.7 \mathrm{~kW}$ and the highest for the case Novi Sad WT $10 \mathrm{~kW}$ and PV $4.35 \mathrm{~kW}$.

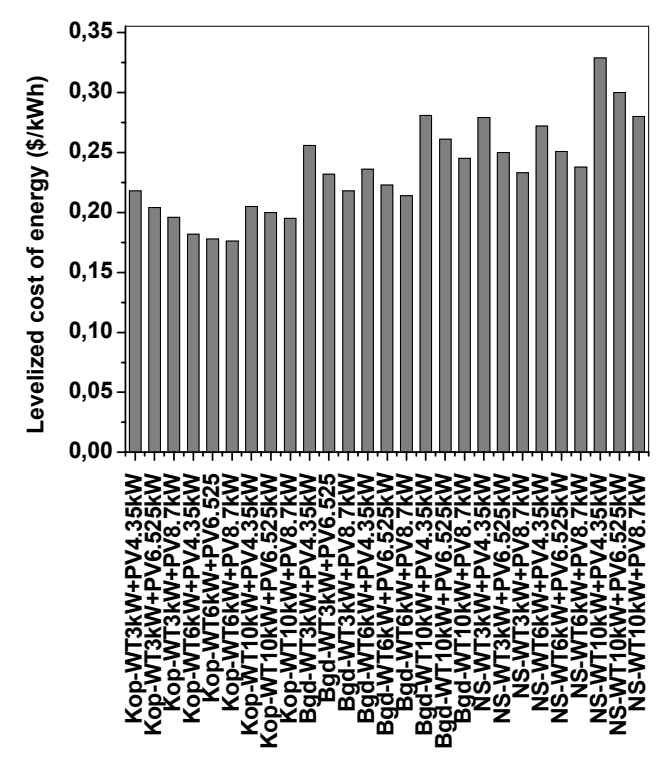

Figure 12. Levelized cost of energy (LCOE)

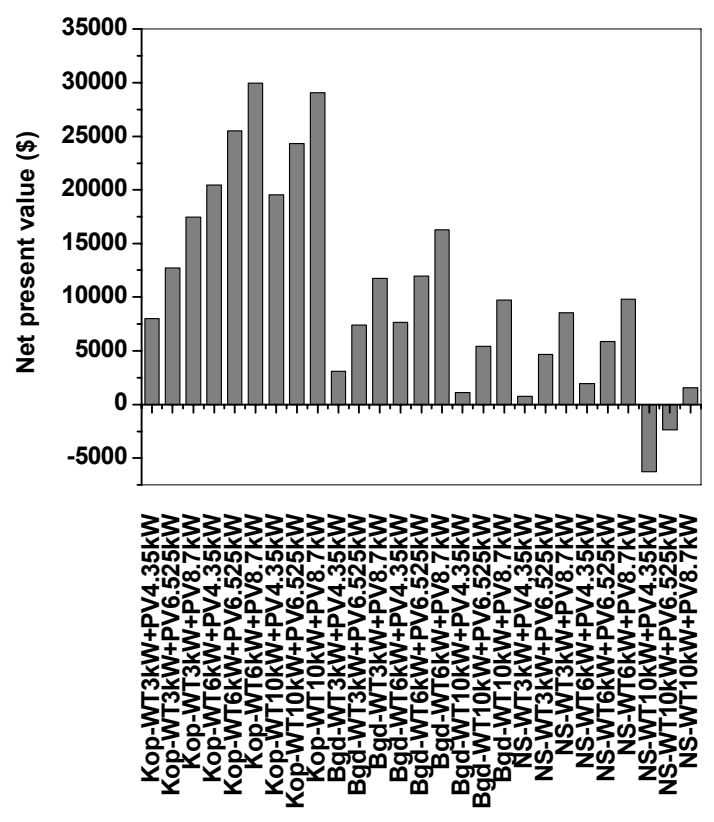

Figure 13. Net present value.

The Net Present Value (NPV) is one way of examining costs and revenues together. A project's net present value is a measure of a project's economic feasibility that includes both cost and revenue. A positive NPV indicates an economically feasible project, while a negative NPV indicates an economically infeasible project. Figure13 shows Net present value for different cases.

Figure 13 shows that the net present value for analysis period of 20 years depends on the location of the energy systems and selection of wind turbines. The most economically feasible cases are for Kopaonik (WT $6 \mathrm{~kW}+$ PV $8.7 \mathrm{~kW})$, NPV is $\$ 30000$. The worst case is for Novi Sad (WT $10 \mathrm{~kW}+$ PV 4.35), with negative NPV.

The annual real interest rate has a great impact on the net present value. In this paper, the economic analysis was performed with the value of the annual real interest rate of $6 \%$. The Fig. 14 shows the effect of annual real interest rate $4-8 \%$ on the net present value 
in cases of Kopaonik, with the highest NPV, and Novi Sad, with the highest negative NPV. Analysis of the impact of annual real interest rate upon net present value indicates the importance of the banking sector in the popularization of renewable energy. If interest rates are lower, the projects will be cost-effective Fig. 14.

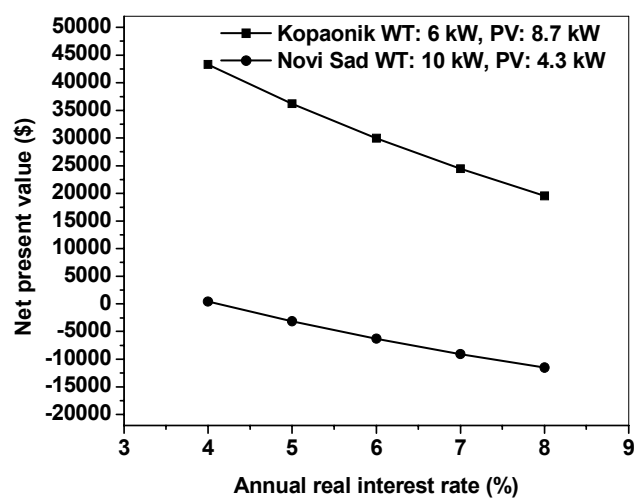

Figure 14. Net present value vs. annual real interest rate curves.

Simple Payback Period (SPP) is the number of years necessary to recover the project cost of an investment under consideration. That is a simple and quick way to compare alternative projects. The drawback to the SPP method is that it ignores the time value of the money. The Discounted Payback Period (DPP) is the number of years necessary to recover the project cost of an investment while accounting for the time value of money. When accounting for the time value of the money, the payback period is longer. In Fig. 15 are shown SPP and DPP for 6 cases.

Finally, it can be concluded that the economic analysis that is based on a number of technical and economic factors, as in this study, may provide a better understanding of the economic feasibility of the project, as well as the impact of the technical characteristics of the equipment and climatic conditions of a region on the economic indicators.

\section{CONCLUSIONS}

The techno-economic analysis of grid-connected PV/Wind power system consisting of various wind turbines and photovoltaic arrays for different locations in Serbia are presented. The study is realized by using the meteorological data for Typical Meteorological Year (TMY) for Novi Sad, Belgrade and national park Kopaonik, Serbia. These three locations are representative locations with different climatic conditions. Transient simulation software TRNSYS and HOMER were used for this purpose. Type 94, 5parameter model for PV arrays and Type 90 wind energy conversion system were selected for this analysis. As a result of the dynamic simulations the electrical power output is obtained for various configurations of the considered system. It is clear that the amount of electric power obtained from gridconnected PV/Wind hybrid energy station strongly depends on the location in Serbia. It is shown that Kopaonik has the greatest RES potential because of its geographical position and climatic conditions. The resulting $\mathrm{CO}_{2}$ emissions reduction is estimated in this paper. The Serbian Government adopted a Decree on the Requirements for obtaining the Status of the Privileged Power Producer and the Criteria for Assessing Fulfillments of these Requirements.

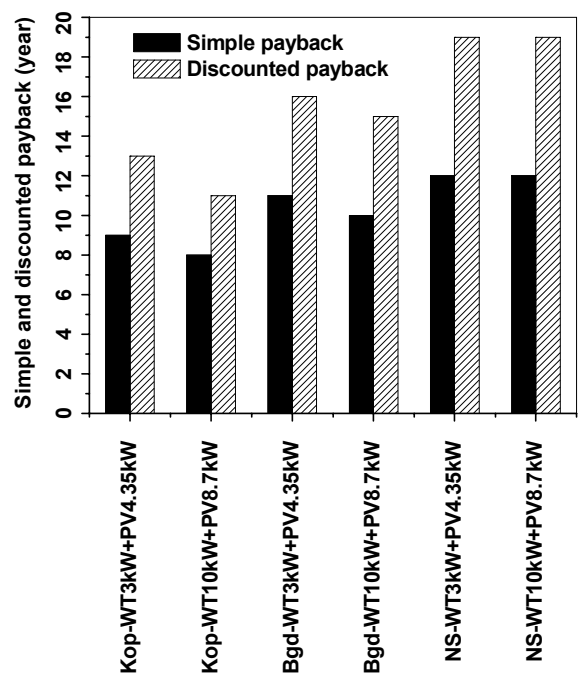

Figure 15. Simple and discounted payback periods

Usage of small PV/Wind energy systems can be increased only if Ministry of Energy of Republic of Serbia increases feed-in tariff for electrical power generated from wind turbines. Economic analysis based on LCC and SPP allows us to rank proposed systems, according to different economic criteria.

\section{ACKNOWLEDGMENT}

This paper is the result of the investigations carried out within the scientific project TR33036 supported by the Ministry of Education, Science and Technological Development of the Republic of Serbia.

\section{REFERENCES}

[1] Erdinc, O., Uzunoglu, M.: Optimum design of hybrid renewable energy systems: Overview of different Approaches, Renewable and Sustainable Energy Reviews, Vol.16, pp. 1412-1425, 2012.

[2] Nema, P., Nema, R.K., Rangnekar, S.: A current and future state of the art development of hybrid energy system using wind and PV-solar: A review, Renewable and Sustainable Energy Reviews, Vol. 13, pp. 2096-2103, 2009.

[3] Li-qun, L., Zhi-xin, W.: The development and application practice of wind-solar energy hybrid generation systems in China, Renewable and Sustainable Energy Reviews, Vol. 13, pp. 1504$1512,2009$.

[4] Caballero, F., Sauma, E., Yanine, F.: Business optimal design of a grid-connected hybrid PV (photovoltaic)-wind energy system without energy storage for an Easter Island's Block, Energy, Vol. 61, pp. 248-261, 2013.

[5] Celik, A.N.: Techno-economic analysis of autonomous PV-wind hybrid energy systems using 
different sizing methods, Energy Conversion and Management, Vol. 44, pp. 1951-1968, 2003.

[6] Suresh, K.U.: Manoharan P.S., Economic analysis of hybrid power systems (PV/diesel) in different climatic zones of Tamil Nadu, Energy Conversion and Management, Vol. 80, pp. 469-476, 2014.

[7] Bortolini, M., Gamberi, M., Graziani, A.: Technical and economic design of photovoltaic and battery energy storage system, Energy Conversion and Management, Vol. 86, pp. 81-92, 2014.

[8] Essalaimeh, S., Al-Salaymeh, A., Abdullat, Y.: Electrical production for domestic and industrial applications using hybrid PV-wind system, Energy Conversion and Management, Vol. 65, pp. 736 $743,2013$.

[9] Caballero, F., Sauma, E., Yanine, F.: Business optimal design of a grid-connected hybrid PV (photovoltaic)-wind energy system without energy storage for an Easter Island's Block, Energy, Vol. 61, pp. 248-261, 2013.

[10] Muralikrishna, M., Lakshminarayana, V.: Hybrid (solar and wind) energy systems for rural electrification, ARPN J Eng Appl Sci, Vol. 5, pp. 50-58, 2008.

[11] Kaabeche, A., Belhamel, M., Ibtiouen, R.: Optimal sizing method for stand-alone hybrid PV/wind power generation system, Energy, Vol. 36, pp. 1214-1222, 2011.

[12] Supriya, C., Siddarthan, M.: Optimization and sizing of a grid-connected hybrid PV-Wind energy system, Int J Eng Sci Technol, Vol. 3, pp. 42964323, 2011.

[13] Ismail, M.S., Moghavvemi, M., Mahlia T.M.I.: Design of an optimized photovoltaic and microturbine hybrid power system for a remote small community: Case study of Palestine, Energy Conversion and Management, Vol. 75, pp. 271281, 2013.

[14] Alsayegh, O., Alhajraf, S., Albusairi, H.: Gridconnected renewable energy source systems: Challenges and proposed management schemes, Energy Conversion and Management, Vol. 51, pp. 1690-1693, 2010.

[15] Nelson, D.B., Nehrir, M.H., Wang, C.: Unit sizing and cost analysis of stand-alone hybrid wind/PV/fuel cell power generation systems, Renewable Energy, Vol. 31, pp. 1641-1656, 2006.

[16] Chong, L., Xinfeng, G., Yuan, Z., Chang, X., Yan, R., Chenguang, S., Chunxia, Y.: Techno-economic feasibility study of autonomous hybrid battery power system for a household in Urumqi, China, Energy, Vol. 55, pp. 263-272, 2013.

[17] Bueno, C., Carta, J.A.: Wind powered pumped hydro storage systems, a means of increasing the penetration of renewable energy in the Canary Islands, Renewable and Sustainable Energy Reviews, Vol. 10, pp. 312-340, 2006.

[18] Caralis, G., Papantonis, D., Zervos, A.: The role of pumped storage systems towards the large scale wind integration in the Greek power supply system,
Renewable and Sustainable Energy Reviews, Vol. 16, pp. 2558-2565, 2012.

[19] Katsaprakakis, D. Al., Christakis, D. G.: Seawater pumped storage systems and offshore wind parks in islands with low onshore wind potential. A fundamental case study, Energy, Vol. 66, pp. 470486, 2014.

[20] Dinglin, L., Yingjie, C., Kun, Z., Ming, Z.: Economic evaluation of wind-powered pumped storage system, Systems Engineering Procedia, Vol. 4, pp. 107-115, 2012.

[21] Bagdanavicius, A., Jenkins, N.: Exergy and exergoeconomic analysis of a Compressed Air Energy Storage combined with a district energy system, Energy Conversion and Management, Vol. 77, pp. 432-440, 2014.

[22] Safaei, H., Keith, D.W.: Compressed air energy storage with waste heat export: An Alberta case study, Energy Conversion and Management, Vol. 78, pp. 114-124, 2014.

[23] Yin, J., Wang, D.Z., Kim, Y.T., Lee, Y.H.: A hybrid energy storage system using pump compressed air and micro-hydro turbine, Renewable Energy, Vol. 65, pp. 117-122, 2014.

[24]Bakić, V., Pezo, M., Stevanović, Ž., Živković, M., Grubor, B.: Dynamical simulation of PV/Wind hybrid energy conversion system, Energy, Vol. 45, pp. 324-328, 2012.

[25] Komarov, D., et al.: Prospects of wind energy sector development in Serbia with relevant regulatory framework overview, Renewable and Sustainable Energy Reviews, Vol. 16, pp. 2618-2630, 2012.

[26] Schneider, D., et al.: Mapping the potential for decentralized energy generation based on RES in Western Balkans, Thermal Science, Vol.11, pp.7-26, 2007.

[27] Pavlović, M., Milosavljević, D., Pirsl, D.: Simulation of photovoltaic systems electricity generation using Homer software in specific locations in Serbia, Thermal Science, Vol. 17, pp. 333-347, 2013.

[28]Lo Brano, V., Orioli, A., Ciulla, G., Di Cangi, A.: An improved five-parameter model for photovoltaic modules, Solar Energy Materials \& Solar Cells, Vol. 94, pp. 1358-1370, 2010.

[29] De Soto, W., et al.: Improvement and validation of a model for photovoltaic array performance, Solar Energy, Vol. 80, pp. 78-88, 2006.

[30] Jianbo, B., Sheng, L., Yuzhe, H., Zhen, Z., Meng, J., Yu, Z.: Development of a new compound method to extract the five parameters of PV modules, Energy Conversion and Management, Vol. 74, pp. 294-303, 2014.

[31] Stefanović, P., Marković, Z., Bakić, V., Cvetinović, D., Spasojević, V., Živković, N.: Evaluation of Kolubara lignite carbon emission characteristics, Thermal Science, Vol. 16, pp. 805-816, 2012.

[32] Short, W., Packey, D.J., Holt, T. A.: Manual for the Economic Evaluation of Energy Efficiency and Renewable Energy Technologies, NREL/TP-4625173, March 1995. 


\section{NOMENCLATURE}

$A_{\mathrm{R}} \quad$ blades area (m2)

$C_{\mathrm{n}} \quad$ cost in period n (\$)

COE cost of energy $(\$ / \mathrm{kWh})$

$C_{\mathrm{p}} \quad$ power coefficient $\left(\mathrm{Js}^{2} / \mathrm{kgm}^{2}\right)$

$d \quad$ annual discount rate

DPP Discounted Payback Period (year)

$G_{\mathrm{T}} \quad$ total radiation incident on PV array

I current (A)

$\mathrm{I}_{\mathrm{L}} \quad$ module photocurrent (A)

$\mathrm{I}_{0} \quad$ diode reverse saturation current (A)

$\mathrm{I}_{\mathrm{L}, \text { ref }} \quad$ module photocurrent at reference conditions (A)

$\mathrm{I}_{\mathrm{sc}, \mathrm{ref}} \quad$ short-circuit current at reference conditions (A)

$\mathrm{I}_{\mathrm{o}, \mathrm{ref}} \quad$ diode reverse saturation current at reference conditions (A)

$\mathrm{I}_{\mathrm{mp}, \mathrm{ref}} \quad$ current at maximum power point along IV curve at reference conditions (A)

IAM incidence angle modifier

$\mathrm{I}_{\mathrm{sc}} \quad$ short circuit current (A)

$I_{\mathrm{mp}} \quad$ maximum power current $(\mathrm{A})$

$k \quad$ Boltzmann constant $(\mathrm{J} / \mathrm{K})$

LCOE Levelized Cost of Energy $\left(\$ / \mathrm{kWh}_{\mathrm{e}}\right)$

NPV Net Present Value (\$)

NOCT nominal operating cell temperature (K)

$p\left(\frac{u}{U}\right) \quad$ probability density distribution (-)

$R_{\mathrm{S}} \quad$ module series resistance $(\Omega)$

$R_{\mathrm{sh}} \quad$ module shunt resistance $(\Omega)$

SRC standard rating conditions

SPP Simple Payback Period (year)

$T_{\mathrm{a}} \quad$ ambient temperature $(\mathrm{K})$

$T_{\mathrm{c}} \quad$ module temperature $(\mathrm{K})$

TLCC total life-cycle cost (\$)

$u \quad$ instantaneous wind speed component $(\mathrm{m} / \mathrm{s})$

$U \quad$ velocity $(\mathrm{m} / \mathrm{s})$

$U_{\mathrm{L}} \quad$ array thermal loss coefficient

$V_{\mathrm{mp}} \quad$ voltage $(\mathrm{V})$

$V_{\text {mp,ref }} \quad$ voltage at maximum power point along $I V$ curve at reference conditions $(\mathrm{V})$

$V_{\text {oc }} \quad$ open circuit voltage (V)
$V_{\text {oc,ref }} \quad$ open-circuit voltage at reference conditions $(\mathrm{V})$

q electron charge constant

$\mathrm{Q}_{\mathrm{n}} \quad$ energy output $\left(\mathrm{kWh}_{\mathrm{e}}\right)$

$\mathrm{z} \quad$ height $(\mathrm{m})$

\section{GREEK SYMBOLS}

$\alpha \quad$ wind speed profiles factor

$\alpha_{\text {Isc }} \quad$ short circuit current (A)

$\beta_{\mathrm{Voc}} \quad$ temperature coefficients at open circuit voltage

$\gamma \quad$ empirical PV curve-fitting parameter

$\rho \quad$ air density $\left(\mathrm{kg} / \mathrm{m}^{3}\right)$

\section{ТЕХНИЧКА И ЕКОНОМСКА АНАЛИЗА ХИБРИДНОГ (РV/ВЕТАР) ЕНЕРГЕТСКОГ СИСТЕМА У РЕПУБЛИЦИ СРБИЈИ У РАЗЛИЧИТИМ КЛИМАТСКИМ УСЛОВИМА}

\section{Вукман Бакић, Милада Пезо, Саша Стојковић}

У овом раду је представљена техничка и економска анализа енергетског система PV/ветар који је повезан са дистрибутивном мрежом у Републици Србији. Технички и економски подаци за хибридне системе за три различите локације: Нови Сад, Београд и Копаоник су добијени користећи софтвере за симулацију: TRNSYS и HOMER. Резултати ове анализе показују да локација и техничке карактеристике енергетског система имају значајан утицај на количину електричне енергије која се испоручи мрежи. Такође је у раду анализирано и смањење емисије $\mathrm{CO}_{2}$. Економска анализа је спроведена помоћy Life Cycling Cost (LCC) методе. Усвајање и примена feed-in тарифа има значајну улогу у повећању употребе технологија које користе обновљиве изворе енергије. 